\title{
Heartburn and effective herbal remedies: A systematic review study in Iranian ethnobotanical documents
}

\author{
Gholam Basati $^{1}$, Pardis Ghanadi ${ }^{\circledR}$, Pegah Shakib $^{3}$, Majid Hamidi ${ }^{*}{ }^{*}$, Peyman Amanolahi Baharvand $^{5^{\circledR}}$ \\ ${ }^{1}$ Biotechnology and Medicinal Plants Research Center, Ilam University of Medical Sciences, Ilam, Iran \\ ${ }^{2}$ Medical Student, Lorestan University of Medical Sciences, Khorramabad, Iran \\ ${ }^{3}$ Razi Herbal Medicines Research Center, Lorestan University of Medical Sciences, Khoramabad, Iran \\ ${ }^{4}$ Department of Pediatrics, Shahrekord University of Medical Sciences, Shaharekord, Iran \\ ${ }^{5}$ Department of English, School of Medicine, Lorestan University of Medical Sciences, Khorramabad, Iran
}

\section{A R T I C L E I N F O}

\section{Article Type:}

Review

\section{Article History:}

Received: 4 May 2020

Accepted: 21 September 2020

\section{Keywords:}

Digestive problem

Heartburn

Anethum graveolens

Mentha pulegium

Medicinal plants

Ethnobotany

Iran

\begin{abstract}
A B S T R A C T
Every year, millions of people worldwide get sick with gastrointestinal diseases such as heartburn. Certain herbs contribute to the alleviation of heartburn, nausea, and improvement of digestion. Moreover, these herbs do not have as many side effects as synthetic drugs. As a health problem and one of the challenging issues in medical sciences, heartburn is common in children and adults worldwide. Hence, in the present study, we tried to report medicinal plants used in cultures and traditions of different regions of Iran to treat heartburn in children and adults. In this review study, articles of Iranian ethnobotanical sources were searched with the keywords of ethnobotanics, heartburn, children, adult, medicinal plants, and Iran. Journal articles published from 2010 to 2019 in several Iranian and International databases, including ISI Web of Science, PubMed, Scopus, ISC, and Magiran, were searched to find relevant articles and information. Anethum graveolens L., Punica granatum L., Mentha pulegium, Thymus kotschyanus Boiss. \& Hohen., Achillea millefolium, Ocimum basilicum, Nigella sativa, etc., are the plants used in different parts of Iran to treat heartburn. Hence, these medicinal plants might be considered as a natural source for preparation of new drugs to treat heartburn.
\end{abstract}

Implication for health policy/practice/research/medical education:

This review provides a detailed insight into the medicinal plants effective on heartburn and shows that Iranian ethnobotanical sciences provide a list of natural treatments for heartburn, which can be used as a reliable source for preparation of new drugs for children and adult.

Please cite this paper as: Basati GH, Ghanadi P, Shakib P, Hamidi M, Amanolahi-Baharvand P. Heartburn and effective herbal remedies: A systematic review study in Iranian ethnobotanical documents. J Herbmed Pharmacol. 2021;10(2):149-155. doi: 10.34172/jhp.2021.16.

\section{Introduction}

Every year, millions of people around the world get sick with gastrointestinal diseases such as heartburn, gastroenteritis, bloating and indigestion. Digestive problems might be a sign of a more severe illness. Moreover, simple problems such as swallowing too much air, eating high-fat foods, eating toxic foods, and even stress can cause simple abdominal pain (1-3). Heartburn is among the common digestive problems. There are several reasons that cause this problem, which affects all the organs in the abdomen, though it is transient in most cases (4-6). The most common symptoms of heartburn include nausea, abdominal pain, bloating, gas or belching loss of appetite, and associated diarrhea. Possible causes for diarrhea and heartburn include stomach flu, premenstrual syndrome, food poisoning, food allergies, lactose intolerance, irritable bowel syndrome, intestinal obstruction, stool fractures, appendicitis, colitis, bacterial infection, stress, anxiety, drug allergies, certain types of cancer, and parasites (79). Colic is an acute and unexpected abdominal pain. In children, it is a syndrome characterized by a self-limiting set of behaviors in the first 3 months of secondary life to underlying gastrointestinal disorders and is a sign of intestinal pain. When a baby is born, his digestive system becomes involved in learning the process of feeding and excretion. This system must adapt to eating and drinking. Hence, some ailments such as heartburn, bloating and diarrhea could be considered normal, although they can 
upset the baby (10-12).

Herbs are used to treat common side effects of various diseases, and heartburn is one of the most common gastrointestinal side effects from which many people suffer (13). Medicinal plants are ethnobotanical and ethnopharmacological sources for the treatment of diseases. Studies have indicated the active ingredients and medicinal as well as antioxidant compounds of medicinal plants enable them not only to have beneficial effects on human health but also to have therapeutic effects on various organs of the body and various diseases (14-20). Some herbs contribute to the alleviation of heartburn, nausea, and improvement of digestion. Furthermore, although these herbs do not have as many side effects as chemicals, they should not be taken without a prescription from a traditional healer. Useful herbs are found in nature and could be used to treat stomach ailments and disorders. Some studies have shown that many of these plants cure diseases even better than chemical drugs. These plants also have no side effects unlike chemical drugs. Heartburn is common in both children and adults worldwide and is one of the health problems and challenges of medical science. Hence, in this study, we tried to report medicinal plants used in cultures and traditions of different regions of Iran to treat heartburn in children and adults.

\section{Methods}

In this review study, the articles of Iranian ethnobotanical sources were searched with the keywords of ethnobotanics, heartburn and Iran. We searched for articles and information published from 2010 to 2019 in databases inside and outside Iran, including ISI Web of Science, PubMed, Scopus, ISC, and Magiran. In the present study, 48 articles were searched. There were two duplicate articles that were omitted. Three articles also lacked full text. Out of the 43 remained articles, only 15 articles contained ethnobotanical information on heartburn in children and adults in Iran. The flowchart of the search strategy and the criteria for entering and leaving the articles is specified in Figure 1.

\section{Results}

Anethum graveolens L., Punica granatum L., Mentha pulegium, Thymus kotschyanus Boiss. \& Hohen., Achillea millefolium, Ocimum basilicum, Nigella sativa, etc., are the plants used in different parts of Iran to treat heartburn. Additional information on the medicinal plants, scientific name, plant family name, the area used and the organs used have been listed in Table 1. The chemical composition of each herbal plant can exert a variety of medicinal properties, including therapeutic properties, on gastrointestinal disorders and syndromes. In this study, the main chemical compounds of each herb were also reviewed and extracted. The main chemical compounds and formulas of each medicinal plant have been listed in Table 1.

\section{Discussion}

Ethno-botany focuses on using plants by a particular ethnic group in an area of plants and is useful for extracting indigenous knowledge of medicinal plants used to treat various diseases. Different regions of Iran

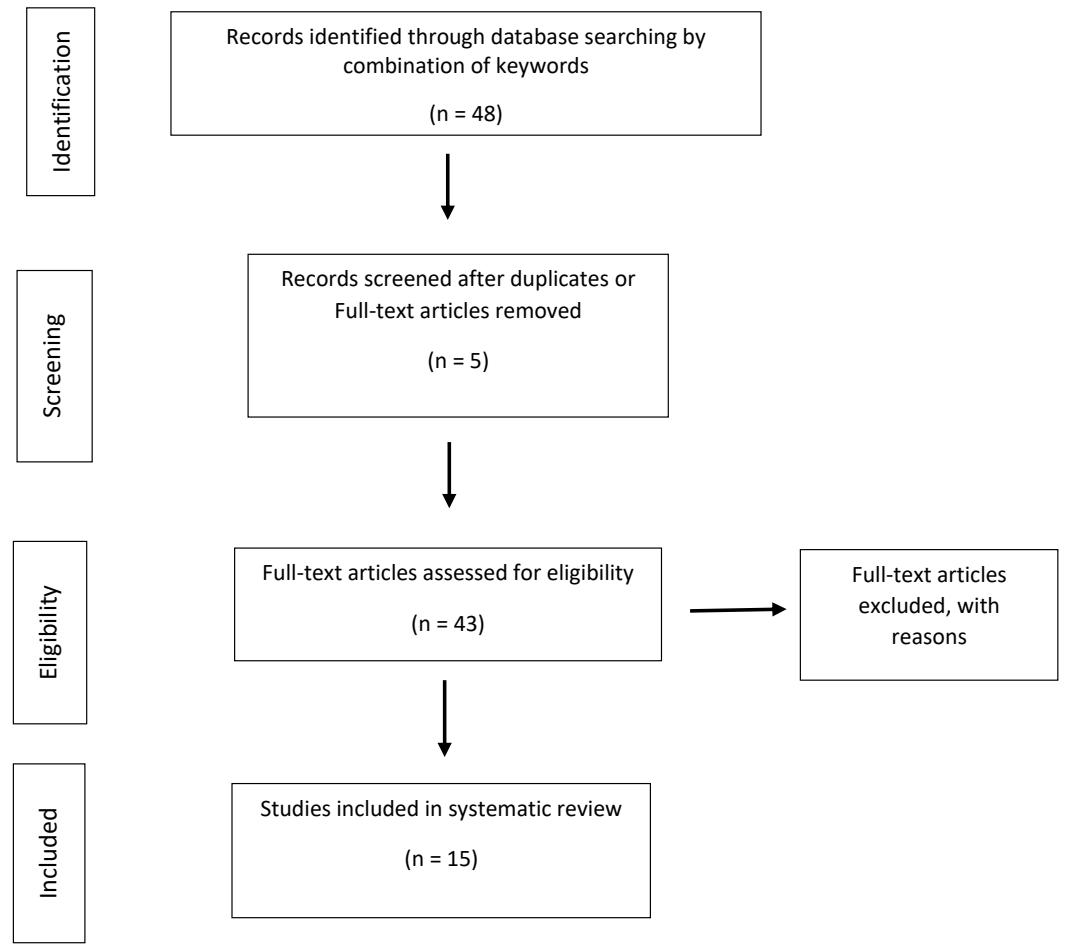

Figure 1. The criteria and the number of entry and exit articles. 
Table 1. Anti- heartburn plants based on Iranian ethnobotanical sources

\begin{tabular}{|c|c|c|c|c|c|c|}
\hline Scientific name & Herbal family & Persian name & Used organ & Region & Main compound & Chemical formula \\
\hline Foeniculum vulgare Mill. & Apiaceae & Razianeh & Fruit, branches and leaves & East Khuzestan (21) & Trans-Anethole & $\mathrm{C}_{10} \mathrm{H}_{12} \mathrm{O}$ \\
\hline Heracleum persicum Desf. ex Fisch., C.A.Mey. \& Avé-Lall. & Apiaceae & Golpar & Fruits and leaves & East Khuzestan (21) & 1-Octanol & $\mathrm{C}_{8} \mathrm{H}_{18} \mathrm{O}$ \\
\hline Achillea millefolium $\mathrm{L}$. & Asteraceae & Boomadaran & Flowering branch & East Khuzestan (21) & Borneol & $\mathrm{C}_{10} \mathrm{H}_{18} \mathrm{O}$ \\
\hline Anthemis cotula L. & Asteraceae & Babouneh bahareh & Flowering branch & East Khuzestan (21) & N-Nonadecane & $\mathrm{C}_{19} \mathrm{H}_{40}$ \\
\hline Biebersteinia multifida DC. & Biebersteiniaceae & Bahmanpish & Fruits & East Khuzestan (21) & Vasicinone & $\mathrm{C}_{11} \mathrm{H}_{10} \mathrm{~N}_{2} \mathrm{O}_{2}$ \\
\hline Phlomis olivieri Benth. & Lamiaceae & Balegoush & Flower & East Khuzestan (21) & Germacrene D & $\mathrm{C}_{15} \mathrm{H}_{24}$ \\
\hline Fritillaria imperialis L. & Liliaceae & Laleh vazhgoun & Fruits and Bulb & East Khuzestan (21) & 3-Methyl-2-butene-1-thiol & $\mathrm{C}_{5} \mathrm{H}_{10} \mathrm{~S}$ \\
\hline Trifolium pratenese L. & Papilionacea & Shabdar & Flower, leaves & East Khuzestan (21) & Scopoletin & $\mathrm{C}_{10} \mathrm{H}_{8} \mathrm{O}_{4}$ \\
\hline Plantago lanceolata $\mathrm{L}$. & Plantaginaceae & Kardeh & Leaves & East Khuzestan (21) & Acteoside & $\mathrm{C}_{29} \mathrm{H}_{36} \mathrm{O}_{15}$ \\
\hline Eremostachys laciniata (L.) Bunge & Lamiaceae & Chele daghi & Root & Ahar and Arasbaran (22) & Dodecanol & $\mathrm{C}_{12} \mathrm{H}_{26} \mathrm{O}$ \\
\hline Thymus kotschyanus Boiss. \& Hohen. & Lamiaceae & Avishan & Flowering branch & Abadeh Fars (23) & Thymol & $\mathrm{C}_{10} \mathrm{H}_{14} \mathrm{O}$ \\
\hline Nigella sativa L. & Caryophyllaceae & Siah daneh & Seeds & Behbahan (24) & Trans-Anatole oxide & $\mathrm{C}_{10} \mathrm{H}_{12} \mathrm{O}_{2}$ \\
\hline Astragalus adscendens Boiss. \& Hausskn. & Fabaceae. & Gavan & Root & Behbahan (24) & Phenol & $\mathrm{C}_{6} \mathrm{H}_{5} \mathrm{OH}$ \\
\hline Rubus anatolicus Focke & Rosaceae & Tameshk derakhti & Aerial organs & Behbahan (24) & Phenol & $\mathrm{C}_{6} \mathrm{H}_{5} \mathrm{OH}$ \\
\hline Plantago lanceolata $\mathrm{L}$ & Plantaginaceae & Barhang sarneyzei & Seed and leaves & Chopar Kerman (25) & Acteoside & $\mathrm{C}_{29} \mathrm{H}_{36} \mathrm{O}_{15}$ \\
\hline Mentha langifolia & Lamiaceae & Poutinek & Aerial organs, root & Chaharbagh Golestan (26) & Cineole & $\mathrm{C}_{10} \mathrm{H}_{18} \mathrm{O}$ \\
\hline Rosa canina L. & Rosaceae & Noghtebandi & Fruit, flower and root & Zanjan (27) & linoleic acid & $\mathrm{C}_{18} \mathrm{H}_{32} \mathrm{O}_{2}$ \\
\hline Ziziphora tenuior $\mathrm{L}$. & Lamiaceae & Gavehzang & Root & Zanjan (27) & Phenol & $\mathrm{C}_{6} \mathrm{H}_{5} \mathrm{OH}$ \\
\hline Achillea millefolium $\mathrm{L}$. & Asteraceae & Boumadaran & Flowering branch & Sajasrood (28) & Borneol & $\mathrm{C}_{10} \mathrm{H}_{18} \mathrm{O}$ \\
\hline Ziziphora clinopodioides L. & Lamiaceae & kakouti & Aerial organs & Sajasrood (28) & Pulgon & $\mathrm{C}_{10} \mathrm{H}_{16} \mathrm{O}$ \\
\hline Anethum graveolens $\mathrm{L}$. & Apiaceae & Shevid & Seeds & Sirjan Kerman (29) & Alpha-Phellandrene & $\mathrm{C}_{10} \mathrm{H}_{16}$ \\
\hline Coriandrum sativum $\mathrm{L}$. & Apiaceae & Geshniz & Stem, leaves and seeds & East Persian Gulf (30) & Alpha-Pinene & $\mathrm{C}_{10} \mathrm{H}_{16}$ \\
\hline Artemisia scoparia Waldst. \& Kit. & Asteraceae & Dermane sharghi & Leaves & East Persian Gulf (30) & Absinthin & $\mathrm{C}_{30} \mathrm{H}_{40} \mathrm{O}_{6}$ \\
\hline Punica granatum $\mathrm{L}$. & Punicaceae & Anar & Fruits & East Persian Gulf (30) & 3,3'-Di-O-Methylellagic acid & $\mathrm{C}_{16} \mathrm{H}_{10} \mathrm{O}_{8}$ \\
\hline Foeniculum vulgare Miller. & Apiaceae & Razianeh & Fruits, branch and leaves & North Khuzestan (31) & Phenol & $\mathrm{C}_{6} \mathrm{H}_{5} \mathrm{OH}$ \\
\hline Heracleum persicum Desf.ex Fischer. & Apiaceae & Golpar & Fruits, Leaves & North Khuzestan (31) & Octyl acetate & $\mathrm{C}_{10} \mathrm{H}_{20} \mathrm{O}_{2}$ \\
\hline
\end{tabular}


Table 1. Continued

\begin{tabular}{|c|c|c|c|c|c|c|}
\hline Scientific name & Herbal family & Persian name & Used organ & Region & Main compound & Chemical formula \\
\hline Prangus ferulacea & Apiaceae & Jashir & Flower, Leaves & North Khuzestan (31) & Alpha-Pinene & $\mathrm{C}_{10} \mathrm{H}_{16}$ \\
\hline Achillea millefolium $\mathrm{L}$. & Asteraceae & Berenjasef & Flowering branch & North Khuzestan (31) & Borneol & $\mathrm{C}_{10} \mathrm{H}_{18} \mathrm{O}$ \\
\hline Anthemis cotula $\mathrm{L}$. & Asteraceae & Babouneh bahareh & Flowering branch & North Khuzestan (31) & N-Nonadecane & $\mathrm{C}_{19} \mathrm{H}_{40}$ \\
\hline Artemisia annua $\mathrm{L}$. & Asteraceae & Bougandou & Leaves & North Khuzestan (31) & 1, 8-Sineol & $\mathrm{C}_{10} \mathrm{H}_{18} \mathrm{O}$ \\
\hline Biebersteinia multifida DC. & Biebersteiniaceae & Bahmanpich & Fruits & North Khuzestan (31) & Alpha-Pinene & $\mathrm{C}_{10} \mathrm{H}_{16}$ \\
\hline Ocimum basilicum L. & Lamiaceae & Riehan & Aerial organs, Seeds & North Khuzestan (31) & Estragole & $\mathrm{C}_{10} \mathrm{H}_{12} \mathrm{O}$ \\
\hline Phlomis olivieri Benth. & Lamiaceae & Balegoush & Flowers & North Khuzestan (31) & Alpha-Pinene & $\mathrm{C}_{10} \mathrm{H}_{16}$ \\
\hline Zataria multiflora Boiss. & Lamiaceae & Avishan shirazi & Aerial organs & North Khuzestan (31) & Carvacrol & $\mathrm{C}_{10} \mathrm{H}_{14} \mathrm{O}$ \\
\hline Fritillaria imperialis $\mathrm{L}$. & Liliaceae & Laleh vazhgoun & Fruits, Bulb & North Khuzestan (31) & Alpha-Bisabolol oxide A & $\mathrm{C}_{15} \mathrm{H}_{26} \mathrm{O}_{2}$ \\
\hline Trifolium pratenese $\mathrm{L}$. & Papilionacea & Shabdar & Flowers, Seeds & North Khuzestan (31) & Pulegone & $\mathrm{C}_{10} \mathrm{H}_{16} \mathrm{O}$ \\
\hline Plantago lanceolata $\mathrm{L}$. & Plantaginaceae & Kardeh & Leaves & North Khuzestan (31) & Linalool & $\mathrm{C}_{10} \mathrm{H}_{18} \mathrm{O}$ \\
\hline Ranunculusarvensis $\mathrm{L}$. & Ranunculaceae & Gole zard & Flowers & North Khuzestan (31) & Phenol & $\mathrm{C}_{6} \mathrm{H}_{5} \mathrm{OH}$ \\
\hline Ducrosia anethifolia (DC.) Boiss. & Apiaceae & Moshgak & Flowers & Fasa (32) & Cis-Chrysanthenyl acetate & $\mathrm{C}_{12} \mathrm{H}_{18} \mathrm{O}_{2}$ \\
\hline Marrubium supinum L. & Lamiaceae & Pouneh kouhi & Flowering branch, Leaves & Fasa (32) & 1,8-Cineole & $\mathrm{C}_{10} \mathrm{H}_{18} \mathrm{O}$ \\
\hline Anethum graveolens $\mathrm{L}$. & Apiaceae & Shevid & Leaves, seeds & Marivan (34) & Alpha-Phellandrene & $\mathrm{C}_{10} \mathrm{H}_{16}$ \\
\hline Hypericum perforatum L. & Fumariaceaea & Houfarighoun & Aerial organs & Marivan (34) & Hypericin & $\mathrm{C}_{30} \mathrm{H}_{16} \mathrm{O}_{8}$ \\
\hline Mentha longifolia L. & Lamiaceae & Pouneh & Flowering branch & Marivan (34) & Pulegone & $\mathrm{C}_{10} \mathrm{H}_{16} \mathrm{O}$ \\
\hline Achillea wilhelmsii C. Koch & Asteraceae: & Boumadaran & Flowers, Leaves & Natanz Kashan (35) & Camphor & $\mathrm{C}_{10} \mathrm{H}_{16} \mathrm{O}$ \\
\hline Launaea acanthodes (Boiss.) O.Kuntze, Revis. & Asteraceae & Charkheh & Flowers, Leaves & Natanz Kashan (35) & Dodecanal & $\mathrm{C}_{12} \mathrm{H}_{24} \mathrm{O}$ \\
\hline Ajuga chamaecistus Ging. Ex Benth. & Lamiaceae & Labdisi boutei & Flowers, Leaves & Natanz Kashan (35) & Geraniol & $\mathrm{C}_{10} \mathrm{H}_{18} \mathrm{O}$ \\
\hline Gailonia brunguieri A. Rich. & Rubiaceae & Galioni & Flowers, Leaves & Natanz Kashan (35) & Artemetin & $\mathrm{C}_{20} \mathrm{H}_{20} \mathrm{O}_{8}$ \\
\hline
\end{tabular}


are characterized by a richness of various medicinal plants and native flora species due to suitable physiotopographic and continental conditions. These plants have been used by Iranians for thousands of years. Overall, ethnobotanical knowledge about medicinal plants in Iran has a remarkable impact on the study and documentation of important information about them.

Anethole is a monomethoxybenzene, which is methoxybenzene substituted in which it has a role as a plant metabolite (36). Borneol is a natural insect repellent (37). It has been shown that vasicinone has an anti-anaphylactic action (38). Thymol can be used as a disinfectant (39). Camphor is used to make moth-proofing products, pharmaceuticals, and flavorings (36). Eucalyptol (cineol) is an ingredient in commercial mouthwashes, and has been used in traditional medicine as a cough suppressant, an insecticide, and an insect repellent (40). $\boldsymbol{\alpha}$-Pinene is an anti-inflammatory agent acting via PGE1. Moreover, it is an antimicrobial agent and a positive modulator of GABAA receptors (41-43). Absinthin shows biological activity and has proved to be a promising anti-inflammatory agent (44). Carvacrol has antimicrobial activity against different bacteria (45). Linalool is used as a flea, fruit fly, and cockroach insecticide (46). Furthermore, it is used in some mosquito-repellent products (47). Hypericin is an antioxidant and antimicrobial compound (48). Geraniol is used as an insect repellent, particularly for mosquitoes (49). Phenols are versatile precursors to an extensive collection of drugs, most notably aspirin, though it is also a precursor to many herbicides and pharmaceutical drugs (50). It is worth noting that antioxidants vary widely in their free-radical quenching effects, and each might be individually attracted to specific cell sites (51). The herbs in this study contain phenolic and antioxidant compounds with extensive medicinal properties such as antimicrobial, anti-parasitic, anti-inflammatory, and analgesic activities. They can treat many disorders and diseases, including digestive problems such as heartburn, or treat their side effects.

In different parts of Iran, various medicinal plants are used to treat gastrointestinal diseases that cause heartburn symptoms and nausea. Kerman's traditional knowledge confirms the use of L. cyminum to treat bloating and colitis (25). In the Arasbaran region of Iran, Berberis vulgaris is used for gastrointestinal problems, Origanum vulgare as a stomach tonic, and Heracleum persicum for digestive problems (22). In Sistan's ethnic botany, Cumin (Cuminum cyminum L.) is used as a painkiller and stomach tonic (37). Traditional knowledge of Shiraz approves the use of Althea aucheri Boiss to treat digestive disorders (33). In Kazerun, Anethum graveolens L. and Anthemis austro-iranica are used to overcome cold symptoms. Moreover, Cichorium intybus is used to strengthen the stomach, and the use of Mentha longifolia is recommended to reduce bloating and stomach acid. Finally, Teucrium polium L. is used to eliminate bloating, and Alcea aucheri is considered a laxative (33). In Mobarakeh, Isfahan, Chamomilla recutita L., Cumin (Cuminum cyminum L.) and Mentha pulegium $\mathrm{L}$ are used to treat diarrhea and strengthen the stomach. Cichorium intybus $\mathrm{L}$ is used to treat constipation (53). In the traditional knowledge of Ilam, Anthemis altissima is used as a food digester, and Cichorium intybus L. is utilized as both a laxative and a reliever of stomach pain (54).

Ethnobotanical studies identify medicinal plants' use as a valuable way to identify efficient medicinal plants (55). Medicinal plants have nutritional and health value, and their useful compounds can be beneficial sources of medicine for the treatment of various disorders $(56,57)$.

It has been indicated that some of the herbs whose beneficial effects on heartburn were reported in this study or previous studies are efficient against diarrhea, stomach pain, and indigestion. Moreover, they have common therapeutic effects with our reported ethnobotanical effects.

Over the past few decades, the study of indigenous pharmacopoeias' knowledge or the traditional use of herbal medicines with the prospect of producing new medication has been on the agenda of many national and international organizations. The positive approach of scientists and the increasing tendency of governments to cooperate in ethnobotanical projects indicate the growing value of the information obtained from these studies. The medicinal plants mentioned above have been traditionally used to treat heartburn.

\section{Conclusion}

Many plants reported in this study contain bioactive compounds, including flavonoids tannins and anthocyanins with antioxidant activities, which are effective in heartburn. Therefore, the results of this study can be highly significant and pave the way for the preparation of natural medicines effective on heartburn.

\section{Authors' contributions}

$\mathrm{GHB}, \mathrm{PGH}, \mathrm{MH}$ reviewed and contributed to data collection and preparation of the manuscript. The first draft was prepared by PGH, MH, PAB. All authors read the final version and confirmed it for publication.

\section{Conflict of interests}

The authors declared no competing interests.

\section{Ethical considerations}

Ethical issues (including plagiarism, data fabrication, double publication and etc.) have been completely observed by the authors.

\section{Funding/Support}

This study received no funding or grant.

\section{References}

1. Delavari A, Moradi G, Birjandi F, Elahi E, Saberifiroozi M. 
The prevalence of gastroesophageal reflux disease (GERD) in the Islamic Republic of Iran: a systematic review. Middle East J Dig Dis. 2012;4(1):5-15.

2. Aziz K, Bonnet D. Hepatogastroenterology. Paris, France: Edition Masson; 2008. p. 322-3.

3. Rosen R, Vandenplas Y, Singendonk M, Cabana M, DiLorenzo C, Gottrand F, et al. Pediatric gastroesophageal reflux clinical practice guidelines: joint recommendations of the North American Society for Pediatric Gastroenterology, Hepatology, and Nutrition (NASPGHAN) and the European Society for Pediatric Gastroenterology, Hepatology, and Nutrition (ESPGHAN). J Pediatr Gastroenterol Nutr. 2018;66(3):516-54. doi: 10.1097/mpg.0000000000001889.

4. Vandenplas Y, Rudolph CD, Di Lorenzo C, Hassall E, Liptak G, Mazur L, et al. Pediatric gastroesophageal reflux clinical practice guidelines: joint recommendations of the North American Society for Pediatric Gastroenterology, Hepatology, and Nutrition (NASPGHAN) and the European Society for Pediatric Gastroenterology, Hepatology, and Nutrition (ESPGHAN). J Pediatr Gastroenterol Nutr. 2009;49(4):498-547. doi: 10.1097/MPG.0b013e3181b7f563.

5. Brouwers MC, Kho ME, Browman GP, Burgers JS, Cluzeau F, Feder G, et al. AGREE II: advancing guideline development, reporting, and evaluation in health care. Prev Med. 2010;51(5):421-4. doi: 10.1016/j.ypmed.2010.08.005.

6. Prather CM. Pregnancy-related constipation. Curr Gastroenterol Rep. 2004;6(5):402-4. doi: 10.1007/s11894004-0057-7.

7. Audu BM, Mustapha SK. Prevalence of gestrointestinal symptoms in pregnancy. Niger J Clin Pract. 2006;9(1):1-6.

8. Clark B, McKendrick M. A review of viral gastroenteritis. Curr Opin Infect Dis. 2004;17(5):461-9. doi: 10.1097/00001432-200410000-00011.

9. Richter JE. Gastroesophageal reflux disease during pregnancy. Gastroenterol Clin North Am. 2003;32(1):23561. doi: 10.1016/s0889-8553(02)00065-1.

10. Nkwi PN. Perceptions and treatment of diarrhoeal diseases in Cameroon. J Diarrhoeal Dis Res. 1994;12(1):35-41.

11. Briggs GG, Freeman RK, Yaffe SJ. Drugs in Pregnancy and Lactation: A Reference Guide to Fetal and Neonatal Risk. Baltimore, USA: Lippincott Williams \& Wilkins; 2002. p. 23-65.

12. Witter FR, King TM, Blake DA. The effects of chronic gastrointestinal medication on the fetus and neonate. Obstet Gynecol. 1981;58(5 Suppl):79S-84S.

13. Nyinoh IW, Atu BO, Oluma HOA. The use of medicinal plants as alternatives for typhoid fever and bacterial gastroenteritis therapy in Abwa-Mbagen, Nigeria. European J Med Plants. 2018;24(2):1-12. doi: 10.9734/ ejmp/2018/42248.

14. Valadi A, Nasri S, Abbasi N, Amin G. Antinociceptive and anti-inflammatory effects of hydroalchoholic extract of Anethum graveolens L. seed. Journal of Medicinal Plants. 2010;9(34):124-30. [Persian].

15. Moayeri A, Azimi M, Karimi E, Aidy A, Abbasi N. Attenuation of morphine withdrawal syndrome by Prosopis farcta extract and its bioactive component luteolin in comparison with clonidine in rats. Med Sci Monit Basic Res. 2018;24:151-8. doi: 10.12659/msmbr.909930.

16. Bahmani M, Taherikalani M, Khaksarian M, Rafieian-
Kopaei M, Ashrafi B, Nazer M, et al. The synergistic effect of hydroalcoholic extracts of Origanum vulgare, Hypericum perforatum and their active components carvacrol and hypericin against Staphylococcus aureus. Future Sci OA. 2019;5(3):FSO371. doi: 10.4155/fsoa-2018-0096.

17. Abbasi N, Khosravi A, Aidy A, Shafiei M. Biphasic response to luteolin in MG-63 osteoblast-like cells under high glucose-induced oxidative stress. Iran J Med Sci. 2016;41(2):118-25.

18. Alizadeh M, Safarzadeh A, Bahmani M, Beyranvand F, Mohammadi M, Azarbaijani K, et al. Brucellosis: pathophysiology and new promising treatments with medicinal plants and natural antioxidants. Asian Pac J Trop Med. 2018;11(11):597-608. doi: 10.4103/1995-7645.246336.

19. Zangeneh $M M$, Ghaneialvar $H$, Akbaribazm $M$, Ghanimatdan M, Abbasi N, Goorani S, et al. Novel synthesis of Falcaria vulgaris leaf extract conjugated copper nanoparticles with potent cytotoxicity, antioxidant, antifungal, antibacterial, and cutaneous wound healing activities under in vitro and in vivo condition. J Photochem Photobiol B. 2019;197:111556. doi: 10.1016/j. jphotobiol.2019.111556.

20. Mahdavi B, Saneei S, Qorbani M, Zhaleh M, Zangeneh A, Zangeneh MM, et al. Ziziphora clinopodioides Lam leaves aqueous extract mediated synthesis of zinc nanoparticles and their antibacterial, antifungal, cytotoxicity, antioxidant, and cutaneous wound healing properties under in vitro and in vivo conditions. Appl Organomet Chem. 2019;33(11):e5164. doi: 10.1002/aoc.5164.

21. Khodayari H, Amani SH, Amiri H. Ethnobotanical study of medicinal plants in different regions of Khuzestan province. Eco-phytochemical Journal of Medicinal Plants. 2015;8(2):12-6. [Persian].

22. Ethnobotanical study of medicinal plants used in AharArasbaran (protected area in East Azerbaijan province of Iran). Mediterr Botany. 2019;40(2):209-14. doi: 10.5209/ mbot.62985.

23. Razmjoui D, Zarei Z, Akbari M. Ethnobotanical study of some medicinal plants of Abadeh city located in Fars province. J Crop Ecol. 2014; 7(3): 222-234.

24. Razmjoue D, Zarei Z, Armand R. Ethnobotanical study (identification, medical properties and how to use) of some medicinal plants of Behbahan city of Khuzestan province, Iran. Journal of Medicinal Plants. 2017;16(64):33-50. [Persian].

25. SHarififar F, Moharam Khani MR, Moattar F, Babakhanloo P, KHodami M. Ethnobotanical study of medicinal plants of Joopar sountains of Kerman province, Iran. Journal of Kerman University of Medical Sciences. 2014;20(1):37-51. [Persian].

26. Ferouzeh MR, Mirdalimi SZ. Study of native herbal medicine and business prioritization related to medicinal plants in Chaharbagh rangelands of Golestan province. J Rangeland Res. 2018;12(4):493-506.

27. Moghanloo L, Ghahremaninejad F, Vafadar M. Ethnobotanical study of medicinal plants in the central district of the Zanjan county, Zanjan province, Iran. J Herb Drugs. 2019;9(3):121-31.

28. Saadatpour M, Barani H, Abedi Sarvestani A, Forouzeh MR. Ethnobotanical study of Sojasrood medicinal plants 
(Zanjan province). J Herb Drugs. 2017;8(3):185-93. doi: 10.14196/jhd.2018.185. [Persian].

29. Khajoei Nasab F, Khosravi AR. Ethnobotanical study of medicinal plants of Sirjan in Kerman province, Iran. J Ethnopharmacol. 2014;154(1):190-7. doi: 10.1016/j. jep.2014.04.003.

30. Rajaei P, Mohamadi N. Ethnobotanical study of medicinal plants of Hezar mountain allocated in South East of iran. Iran J Pharm Res. 2012;11(4):1153-67.

31. Hoveizeh H, Dinarvand M, Salehi H. Medicinal herbs of Khuzistan province. Iranian Journal of Medicinal and Aromatic Plants Research 2002; 14: 55-72.

32. Ramezanian M, MinaeiFar AA. Ethnobotanical study of medicinal plants in Fasa county. Journal of Islamic and Iranian Traditional Medicine. 2016;7(2):221-31.

33. Dolatkhahi M, Ghorbani Nohooji M, Mehrafarin A, Amini Nejad G, Dolatkhahi A. Ethnobotanical study of medicinal plants in Kazeroon, Iran: Identification, distribution and traditional usage. Journal of Medicinal Plants. 2012;11(42):163-78. [Persian].

34. Tabad MA, Jalilian N. Ethnobotanical study of medicinal plants in Zarivar region (Marivan), Iran. Journal of Medicinal Plants. 2015;14(54):55-75. [Persian].

35. Abbasi S, Afsharzadeh S, Mohajeri A. Ethnobotanical study of medicinal plants in Natanz region (Kashan), Iran. J Herb Drugs. 2012;3(3):147-56. [Persian].

36. Waldbott S. Essential oils. Chemical Abstracts. 1920; 14(17):3753-5.

37. Wong KC, Ong KS, Lim CL. Composition of the essential oil of rhizomes of Kaempferia galanga L. Flavour Fragr J. 2006;7(5):263-6. doi: 10.1002/ffj.2730070506.

38. Soni S, Anandjiwala S, Patel G, Rajani M. Validation of different methods of preparation of Adhatoda vasica leaf juice by quantification of total alkaloids and vasicine. Indian J Pharm Sci. 2008;70(1):36-42. doi: 10.4103/0250474x.40329.

39. Evans JD, Martin SA. Effects of thymol on ruminal microorganisms. Curr Microbiol. 2000;41(5):336-40. doi: $10.1007 / \mathrm{s} 002840010145$.

40. Klocke JA, Darlington MV, Balandrin MF. 1,8-Cineole (Eucalyptol), a mosquito feeding and ovipositional repellent from volatile oil ofHemizonia fitchii (Asteraceae). J Chem Ecol. 1987;13(12):2131-41. doi: 10.1007/bf01012562.

41. Russo EB. Taming THC: potential cannabis synergy and phytocannabinoid-terpenoid entourage effects. $\mathrm{Br}$ J Pharmacol. 2011;163(7):1344-64. doi: 10.1111/j.14765381.2011.01238.x.

42. Nissen L, Zatta A, Stefanini I, Grandi S, Sgorbati B, Biavati $\mathrm{B}$, et al. Characterization and antimicrobial activity of essential oils of industrial hemp varieties (Cannabis sativa L.). Fitoterapia. 2010;81(5):413-9. doi: 10.1016/j. fitote.2009.11.010.

43. Yang H, Woo J, Pae AN, Um MY, Cho NC, Park KD, et al. a-Pinene, a major constituent of pine tree oils, enhances non-rapid eye movement sleep in mice through GABAAbenzodiazepine receptors. Mol Pharmacol. 2016;90(5):5309. doi: 10.1124/mol.116.105080.

44. Zhang W, Luo Fang SH, Chen Q, Hu H, Jia X, Zhai H. Total Synthesis of Absinthin. J Am Chem Soc. 2005;127(1):18-19. doi: $10.1021 /$ ja0439219.

45. Andersen A. Final report on the safety assessment of sodium p-chloro-m-cresol, p-chloro-m-cresol, chlorothymol, mixed cresols, m-cresol, o-cresol, p-cresol, isopropyl cresols, thymol, o-cymen-5-ol, and carvacrol. Int J Toxicol. 2006;25 Suppl 1:29-127. doi: 10.1080/10915810600716653.

46. Yang Z, Bengtsson M, Witzgall P. Host plant volatiles synergize response to sex pheromone in codling moth, Cydia pomonella. J Chem Ecol. 2004;30(3):619-29. doi: 10.1023/b:joec.0000018633.94002.af.

47. Wilson D. What to Look for When You're Buying Mosquito Repellent. South China Morning Post; 2015.

48. Karioti A, Bilia AR. Hypericins as potential leads for new therapeutics. Int J Mol Sci. 2010;11(2):562-94. doi: 10.3390/ ijms11020562.

49. Stork G, Grieco PA, Gregson M. Allylic chlorides from allylic alcohols: geranyl chloride. Org Synth. 1974;54:68. doi: 10.15227 /orgsyn.054.0068

50. Weber M, Weber M, Kleine-Boymann M. Phenol. In: Ullmann's Encyclopedia of Industrial Chemistry. Weinheim: Wiley-VCH; 2004. doi: 10.1002/14356007.a19_299.pub2.

51. Alok S, Jain SK, Verma A, Kumar M, Mahor A, Sabharwal M. Herbal antioxidant in clinical practice: a review. Asian Pac J Trop Biomed. 2014;4(1):78-84. doi: 10.1016/s22211691(14)60213-6.

52. Iranmanesh $\mathrm{M}$, Najafi $\mathrm{SH}$, Yousefi $\mathrm{M}$. Ethno-butane study of medicinal plants in Sistan region. J Herb Drugs. 2009;2:61-8. [Persian].

53. Mardani-Nejad SH, Vazirpour M. Ethno-botany of medicinal plants by Mobarakeh's people (Isfahan). J Herb Drugs. 2012;3(2):111-29. [Persian].

54. Ghasemi Pirbalouti A, Momeni M, Bahmani M. Ethnobotanical study of medicinal plants used by Kurd tribe in Dehloran and Abdanan sistricts, Ilam province, Iran. Afr J Tradit Complement Altern Med. 2013;10(2):36885. doi: 10.4314/ajtcam.v10i2.24.

55. Karami N, Karimi M, Bahmani M. Constipation: an ethnobotanical study of medicinal plants used for constipation in Shahrekord city, Chaharmahal \& Bakhtiari province, Iran. Plant Biotechnol Persa. 2020;2(1):1-7.

56. Gholami-Ahangaran M, Ahmadi-Dastgerdi A, KarimiDehkordi M. Thymol and carvacrol; as antibiotic alternative in green healthy poultry production. Plant Biotechnology Persa. 2020;2(1):22-5. doi: 10.29252/pbp.2.1.22.

57. Magbool FF, Elnima EI, Shayoub ME, Osman Z, Adam ME, Hamedelniel EI, et al. Formulation design, development and evaluation of Quercus infectoria galls extract oral gels. Plant Biotechnol Persa. 2020;2(2):1-13. 